Iryna Papa

Ukrainian Catholic University

\title{
Vejen over Lemberg: \\ A Dane's Impressions of Lemberg/Lviv in 1711: \\ Just Juel and His Travels through \\ the Polish-Lithuanian Commonwealth
}

This article analyzes an excerpt from the travel diary of Just Juel, who was a Danish envoy to Peter the Great in 1709-1711. Particular attention is paid to Juel's travel through the Polish-Lithuanian Commonwealth and his visit to Lemberg/Lviv in 1711, its historical context, and possible interpretations based on approaches of cultural history.

Keywords: Just Juel, travel diary, Danish diplomatic mission (1709-1711), the Great Northern War, Lemberg/Lviv

\section{Just Juel and his diplomatic mission (1709-1711)}

Unlike most European travelers, the Danes rarely traveled across Central and Eastern Europe in the early modern epoch ${ }^{1}$. They preferred the Grand Tour as did most Europeans at the time (Brodsky-Porges 1981: 171-186; Jasnowski 1960: 31-36; Jasnowski 2008). An excellent example of this is the European travels of the Danish King Frederick IV (Weilbach 1933). International relations and economic interests were the main reasons royal envoys and trade agents traveled to the Russian state, which was a longtime partner of Denmark in the Baltic region and a frequent political ally in various military conflicts against Sweden.

The Danish diplomatic mission (1709-1711) led by Juel had planned to return Denmark to the Great Northern War arena. According to historians, this mission

1 Marshall Poe composed the bibliography of various travel writings upon Muscovy and East Europe written by the foreigners from the fifteenth century to 1700 . There are only 24 Danish positions among 638 travel descriptions. The most well-known is Jakob Ulfeldt's Hodoeporicon Ruthenicum (Poe 1995). 
was most likely conceived as a kind of reconnaissance and search for convincing arguments for the Danish king and his councillors, who still hesitated about the potential of Tsarist Russia and the right moment to re-engage in the Great Northern War. As far as we know, Juel was an experienced naval officer and traveler (With 1894: 587-590; Paulli 1979-1984; Daae 1884; Garde 1832-1835; Liisberg 1919; Garde 1861; Topsøe-Jensen and Marquard 1935; Lind 1986: 26-72), and these facts somehow revealed the hidden, official intentions of Danish officials.

Several dates can be considered as the beginning of this journey: April 8, 1709 (the first entry in Juel's diary); June 11 (date of the official instructions for the royal envoy); or June 17, which was the actual beginning of this journey. The official conclusion of the mission was the recall of Juel on December 21, 1711. Juel's diplomatic mission can be divided into several stages that have a clear chronological and geographical framework. The first part of this journey lasted from the summer of 1709 to the autumn of 1709. Geographically it covered Denmark, Prussia, and the Baltic territories, which had already been recaptured from the Swedes (i.e., Narva). From the autumn of 1709 to the end of spring in 1711, the Danish envoy stayed at the Petrine court in Moscow but quite often visited Petersburg, Novgorod, and other Russian cities. This Russian period was full of communication with Peter the Great, Russian noblemen, European ambassadors, Orthodox clergymen, and various possibilities to become acquainted with the Russian culture in all of its forms and manifestations. Juel was required to inform the Danish monarch and his councilors about the state of affairs in Russia, so the Danish envoy often had to follow Peter the Great and travel a lot.

The declaration of war by the Ottoman Empire in 1710 added a new turn in his diplomatic journey, unique empiric experience, and further notes in his travel diary. The next part could be defined as Ukrainian as the Danish envoy visited three Ukraines - the Russian, the Cossack, and the Polish (Крикун 1993; Крикун 2012; Шелухин 1936-1937). This stage lasted from early June to mid August 1711.

The last period of his mission spanned August to December 1711, and geographically it covered other Polish-Lithuanian Commonwealth territories. This was the final part of his mission, and Juel completed his diplomatic duties and was officially recalled by the Danish king on December 21 from Gdansk.

Like most royal envoys, Juel was guided by royal instruction, which, in a way, determined the priority of the topics, objects, and personalities he wrote about in his travel notes. Close reading and content analysis of the source show a distinct difference among the travel notes from different periods of this mission.

The Russian period was the longest and differed in details and the variety of impressions and observations. The other parts of the Danish mission, the Ukrainian and the Polish-Lithuanian, are accented differently, and, accordingly, the style of narration and content is due to different contexts and circumstances. The travel notes from this stage of the trip are more descriptive and original, in our opinion, which is why they attracted our attention. 


\section{Just Juel and his travel diary}

The original handwritten diary is preserved in the Danish National Archive (Rigsarkivet). It is a part of the "Just Juels gesandtskabsarkiv (1709-1712)" and "Tyske Kancelli" (Hassø and Kroman 1973; Gigas 1906; Case and Thomas 1975) archival collections ${ }^{2}$. As far as we know, Juel and his secretary, Rasmus Æreboe, compiled this diary from their handwritten drafts after the mission (possibly in 1712 or 1713). Unfortunately, the original travel notes do not survive today. The final version of the diary was composed and rewritten for the Danish king and his counselors.

It was published in the original language by the archivist Gerhard Grove in 1893 (Juel and Grove 1893). The Danish historian outlined that he attempted to "illuminate a source that has been at rest for almost 200 years" (Juel and Grove 1893: I). The publication of this diary was the impetus for the emergence of several reviews in different languages including in French and English (Morfill 1895: 800-805; Rambaud 1894; Rabot 1895; Vuillaume 1895). It also contributed to the publication of a complete translation into Russian by Yurij Shcherbachov (Щербачев 1900).

Later attempts to publish Juel's diary in the twentieth century were deprived of scholarly soundness and criticism because of the compilation and the fragmentary nature of the text (Danielsen 1975), which is why most historians still use thorough publications by Grove and the Russian translation by Shcherbachev.

\section{Historiography}

Historians mainly focus attention on the Russian part of Juel's mission. This is quite understandable since Juel's primary goal was rejse til Rusland. Therefore, most Russian and Danish scholars focus on international relations during the Great Northern War and the image of Peter the Great (selected studies in Danish: Møller 1994; Christensen and Gottlieb 2010; Møller 1997: 48-66; selected studies in Russian: Возгрин 1973: 102-105; Возгрин 1975: 309-327; Возгрин 1982: 148-151; Возгрин 1986; Агеева 2003: 3-13). Unfortunately, other topics and problems in Juel's diary do not attract as much attention from historians. For example, in Ukrainian historiography, Juel's diary is mostly mentioned as an evidence of Ukrainian statehood and its longue durée. Some notes in the diary are also always used to stress the cultural differences between Cossacks (i.e., Ukrainians) and Russians.

Unfortunately, our search for Polish studies that referred to Juel's diary as a primary source did not yield any results. The only work found was a publication by Michal Rolle, a Polish journalist and amateur historian, in the journal Świat in 1895 (Rolle 1895a: 177-178; Rolle 1895b: 203-204; Rolle 1895c: 258-260, 278-282). He translated an excerpt of the diary into Polish, but from the Russian translation

2 VA XI, Tyske Kancelli II, p. 280 TKUA, Speciel del, Rusland 104-107. 
and not from the original Danish text ${ }^{3}$. He chose the part of the diary from June 1711 to September 1711 and added footnotes with commentary on the toponyms and personalities mentioned in the Danish source. Later this Polish translation was published as part of his book with historical essays (Rolle 1908: 345-372). Unfortunately, we did not succeed in finding any critical or academic review of this attempt to acquaint Polish readers with this early modern Danish travelog.

Although there are plenty of thorough studies in Polish historiography of the Great Northern War (Feldman 1925; Wimmer 1956; Gierowski 1971; Popiołek 2002; Radziwonka 2019; Górny and Piwarski 1932), the Polish-Danish relationship (Czapliński and Górski 1965; Czapliński 1976; Lanckorońska 1964-1974; Koczy 1931: 36-69; Ślaski 1967: 111-116; Ślaski 1974; Ślaski 1977; Mączak 1982: 167-180; Schab 2008: 652-660; Schab 2018; Helleberg 1992), travelogs of foreigners in the Polish-Lithuanian Commonwealth (Gintel 1971; Lubas-Bartoszyńska 2012: 199-216; Wilder 1959; Pepłowski 1902), this Danish primary source did not attract the attention of academic historians. It was noted that Polish historians are more focused on Swedish sources and Polish-Swedish relations in the eighteenth century than on Danish primary sources and the Polish-Danish relationship in this period (Majewska 2011:39-60; Majewska 2018: 135-154; Konopczyński 1924; Ciesielski 1990).

Therefore, this aim of this article is to acquaint readers with a excerpt of the diary about Juel's stay in Lemberg/Lviv in 1711 and to apply approaches based on the cultural history of travel (Struk 2005: 154-179; Burke 2010: 1-11; Maczak 1995; Mączak 1998), imagology (Beller and Leerssen 2007: 3-16; Neumann 1999), and mental mapping (Schenk 2002; Harbsmeier 1982a; Wolff 1996) to its analysis.

\section{Preconditions and context of the visit to Lemberg/Lviv}

Juel traveled beyond Petrine Russia because of the war with the Ottoman empire and the Prut campaign in 1711. This was the reason for the forced and unplanned journey to the south, across Russian Ukraine (i.e., the Kyiv Governorate), Cossack Ukraine (i.e., the Cossack Hetmanate), and Polish Ukraine (i.e., the Braclaw and Podole voivodeships).

The military confrontation between Russia and the Ottoman Empire lasted from June 29 to July 10 and ended with negotiations and the Prut Treaty of July 12, 1711.

\footnotetext{
"Russkij Archiv umieścił w kilku zeszytach 1892 r. wyjątki z dziennika duńskiego posła, odbywającego - przed dwustu niespełna laty - peregrynacye po obszarach wchodzących w skład dzisiejszych południowo-zachodnich gubernij. Tusząc, że opis miejscowości, niegdyś do Polski należących, zaciekawić zdoła, powtarzamy odpowiedne ustępy pamiętnika, w polskim - o ile możności dosłownym - przekładzie, korygując równocześnie poprzekręcane przez pana Justa Juel nazwy miast, które wydawca rosyjski ani słówkiem koniecznego wyjaśnienia opatrzyć nie raczył. Omawiany dyaryusz duńskiego turysty z wielu względów do nader ciekawych zaliczonym być musi” (Rolle 1895a: 177).
} 
However, after a long journey from Kyiv, the Danish envoy learned about all these events only on August 2, 1711, from a royal messenger. On August 10, he had the opportunity to meet with Peter I in Mogilev (Grove 1893: 406). Shortly afterward (August 14), the Danish envoy also received new tasks and orders from Chancellor Gavriil Golovkin for a further journey and the next meeting with Peter I. According to the travel diary, Juel received a recommendation to "go through Lemberg to Jaroslaw" (i.e., tage vejen over Lemberg til Jaroslaw) (Juel and Grove 1893: 424). He began his journey on the new route on August 16 from Shargorod. However, the Danish envoy did not arrive in Lemberg/Lviv until August 30.

In his diary, he mentioned desolate, destroyed towns and villages, complained about poor accommodation and various problems along the road to Lemberg/Lviv (i.e., lack of provisions, fear of Tatar attacks, etc.). According to the primary source, Juel lost his translator and several people who died on the way to Lemberg/Lviv. The Dane often complained about exhaustion and health issues. In our opinion, this factor was the main reason for the longer stay in Lemberg/Lviv and the fragmentary character of the notes. According to the diary, Juel arrived in Lemberg/ Lviv on August 30 and stayed in the city until September 6.

\section{Just Juel upon Lemberg/Lviv in 1711}

The excerpt of the diary from Lemberg/Lviv spans 2 folia in origo and almost three pages in the printed edition (Juel and Grove 1893: 428-430). There are several blocks of information in this description: the external characteristics of the city (i.e., walls, castle), internal (i.e., houses, churches, buildings); remarks on the local population (i.e., clothing, gender composition, officials); the political and international context of 1711 (i.e., Russian army in the Polish-Lithuania Commonwealth, the Great Northern War, Tsar Peter I, August II).

This Danish impression of Lemberg/Lviv reminds us of typical descriptions of cities in famous early modern travelogs in which authors focused on fortifications, political power, sacred objects, and other characteristics that did not require extraordinary exploration or effort. As we noted, the descriptions of other cities in the Polish-Lithuanian Commonwealth in this diary are quite similar (e.g., Yaroslaw, Warsaw, Torun).

As a representative of the Danish king and as a person with a military background, he quite aptly mentions the storming and looting of Lemberg/Lviv by the Swedes. Although, to our surprise, it indicates an erroneous date; instead of 1704, he writes "three years ago" (i.e., 1708). We can assume that this was a mistake that could have been made when the final version was composed, or Juel received incorrect information about these events from locals. Also, the military background of Juel is reflected in the description of the High Castle in Lemberg/Lviv. He probably visited it and could personally assess the benefits of its strategic location. 
Most of his observations about the ruined suburb (probably, Galician) and destroyed buildings in the city coincide with evidence from other primary sources on the history of Lemberg/Lviv (Zubrzycki 1844: 451-459). However, there are also apparent flaws in the Danish description of Lemberg/Lviv. For instance, Juel mentions five-story buildings in the city, which seemingly impressed him after the primitive wooden architecture in Petrine Russia and the war-torn cities in Polish Ukraine. But it is a well-known fact that the first floor was mainly technical, not residential. However, other observations of city houses with decorated facades and metal windows coincide entirely with existing houses on Rynok Square. Among other buildings, he singles out the Jesuit College and the church attached to it. Unfortunately, he does not mention other sacred sites in Lemberg/Lviv that he probably saw in the city center (for example, the Latin Cathedral).

Juel also mentions the presence of the Tsarist army in the territory of the Polish-Lithuanian Commonwealth. He briefly analyzes the state of Russian-Polish relations in this historical period, which contributed to the formation of certain negative stereotypes of Swedes and Russians in the Polish mentality (Otwinowski 1849; Rolnik 2002: 290-304; Niewiara 2006; Popiołek 2011: 93-108). This part of the excerpt manifests the Danish diplomatic view of the Russian war methods and apparent abuses suffered by Russian allies (mainly the Polish-Lithuanian Commonwealth). From his observations, the Poles treated the Swedes, who came as enemies, worse than the Russians, who came as friends but continually plundered them. These impressions of the Dane are quite accurate and reflect known facts from other sources (Burdowicz-Nowicki 2010; Koroluk 1954; Kamiński 1966: 234-235, 258; Krokosz 2010).

At the end of this excerpt Juel also mentions some city officials. Cappinghausen, a Swede, according to his testimony, was the commandant in Lemberg/Lviv. Unfortunately, there is no information about this person in the sources or the literature (Мацевко, Мудрий 2016: 27-28).

The Danish traveler's particular observations remind us of some clichés from early modern travelogs on East Europe, which are outlined by the famous historian Larry Wolff. For example, the expression French clothes in the description of locals can be interpreted as a marker of Europeanness and civilization, while Polish clothes is as a sign of traditional Polish-Lithuanian society (Wolff 1994: 182, 240). Such observations could also be evidence of the local/traditional culture and modernization that coexisted in this region.

Since this travel narrative written by a naval officer (Juel) and his secretary-theologian (Æreboe), this set of subjective observations and impressions is like a patchwork. However, even these miscellaneous testimonies of a foreigner are noteworthy. At the beginning of the eighteenth century, the city was in a protracted crisis due to the Great Northern War and the prolonged political and economic situation in the Polish-Lithuanian Commonwealth. This stagnation also affected the lack of sources and the appearance of numerous blank spots 
in the history of Lemberg/Lviv in the early eighteenth century (Hirschberg 1888; Papée 1894; Papée 1924). This issue is also highlighted by other historians, such as Bożena Popiołek ${ }^{4}$.

Thus, this brief travel memoir of the Danish envoy Juel about his short stay in Lemberg/Lviv in 1711 can complete the history of Lemberg/Lviv with some remarks. It is also an interesting primary source for studying Danish perceptions of Eastern Europe, which was often in the shadow of Russia and therefore less frequently visited and described by Scandinavian travelers. Juel's diary notes about the Polish-Lithuanian Commonwealth can also supplement the existing canon of travel writings written by foreigners on the Polish state and its neighbors in the early eighteenth century.

This part of the diary also illustrates well that Tsarist Russia was the central purpose of the diplomatic mission of Juel. Therefore, other states participating in the Great Northern War, through which the Danish embassy traveled across in 1709-1711, received less attention, despite their participation in the war and international politics. As far as we know, the Polish-Lithuanian Commonwealth had long been the central playground for Russian and Swedish confrontations.

The location of the Polish-Lithuanian Commonwealth on the mental and political map was, to some extent, manifested in travel notes on changes in national currencies, the presence of military outposts, and local authorities. Regarding the internal specifics of the Polish state, Juel notes certain cultural and religious differences from its neighbors. It is notable how the descriptions of the war-torn infrastructure of the Commonwealth contrast with the backward or almost absent infrastructure of Petrine Russia; how a multi-ethnic and multi-confessional Poland differs from the monolithic nature of its northeastern neighbor.

Thus, it is clear that Juel and other Danish officials imagined the Polish-Lithuanian Commonwealth as a large but territorially and culturally very heterogeneous European state bordered by Tsarist Russia, Prussia, the Ottoman Empire, and the Habsburg state. Moreover, this neighborhood was the source of constant external problems.

4 "W historii Lwowa w czasach panowania Augusta II przeplatały się chwile tragiczne i okresy względnego spokoju, kiedy życie w mieście toczyło się normalnym rytmem. Kryzys ekonomiczny spowodowany wojną, nieurodzajem i klęskami elementarnymi wywarł ogromny wpływ na sytuację społeczną i gospodarczą miasta, nadal jednak odgrywało ono ważną rolę jako centrum życia politycznego i towarzyskiego w I połowie XVIII w. Jednak dokładne określenie roli Lwowa w czasach saskich wymaga podjęcia gruntownych badań na podstawie źrodeł rękopiśmiennych" (Popiołek 2002: 104). 
Beller, M. and J. Leerssen. (2007). Imagology, the cultural construction and literary representation of national characters, a critical survey. Series: Studia imagologica 10. Amsterdam: Rodopi, pp. 3-16.

Borek, P. (2001). Ukraina w staropolskich diariuszach i pamiętnikach. Bohaterowie, fortece, tradycja. Kraków: Collegium Columbinum.

Borek, P. (2003). Lwów utrapiony in anno 1704 albo Dyjaryjusz wziętego Lwowa przez króla szwedzkiego Karola XII die 6 mensis Septembris anno 1704. Kraków: Collegium Columbinum.

Brodsky-Porges, E. (1981). The Grand Tour Travel as an Educational Device 1600-1800. Annals of Tourism Research 8(2): 171-186.

Burdowicz-Nowicki, J. (2010). Piotr I, August II i Rzeczpospolita 1697-1706. Kraków: Arcana.

Burke, P. (2010). The Cultural History of the Travelogue. Przeglad Historyczny 101(1): 1-11.

Case, L.M. and D.H. Thomas. (1975). The New Guide to the Diplomatic Archives of Western Europe. Philadelphia: University of Pennsylvania Press.

Christensen, S. and H. Gottlieb. (2010). Danmark og Rusland $i 500$ år. København: Dansk Institut for Internationale Studier.

Ciesielski, Z. (ed.). (1990). Relations between Poland and Sweden over the centuries: a collection of studies. Wrocław: Zakład Narodowy im. Ossolińskich. Wydawnictwo Polskiej Akademii Nauk.

Czapliński, W. (1976). Polska a Dania XVI-XX w. Warszawa: PIW.

Czapliński, W. and K. Górski. (1965). Historia Danii. Wrocław-Warszawa-Kraków: Ossolineum.

Daae, L. (1884). Nordmoend og Danske i Rusland i det attende Aarhundrede. Christiania: trykt hos Carl C. Werner \& Co.

Danielsen, J. (1975). Just Juels rejse til Moskva 1709-1711. København: Gad.

Feldman, J. (1925). Polska $w$ dobie Wielkiej Wojny Północnej. 1704-1709. Kraków: Polska Akademia Umiejętności.

Garde, H.G.F. (1832-1835). Efterretninger om den Danske og Norske Søemagt. Vol. 4. Kobenhavn: Paa Udgiverens Forlag.

Garde, H.G.F. (1861). Den dansk-norske Sømagts Historie 1535-1700. København: Bianco Lunos Bogtrykkeri.

Gierowski, J. (1971). W cieniu Ligi Północnej. Wrocław: Zakład Narodowy im. Ossolińskich.

Gigas, E. (1906). Katalog over Det Kongelige Bibliotheks Haandskrifter vedrørende Norden, sarlig Danmark. København: Udg. af Det kongelige Bibliothek.

Gintel, J. (1971). Cudzoziemcy o Polsce. Relacje i opinie. T. 1: WiekX-XVII. T. 2: Wiek XVIII-XIX. Kraków: Wydawnictwo Literackie.

Górny, A. and K. Piwarski. (1932). Kraków w czasie drugiego najazdu Szwedów na Polskę: 1702-1709. Kraków: Nakładem Towarzystwa Miłośników Historyi i Zabytków Krakowa.

Harbsmeier, M. (1982a). Reisebeschreibungen als mentalitätsgeschichtliche Quellen: Überlegungen zu einer historisch-anthropologischen Untersuchung frühneuzeitlicher deutscher Reisebeschreibungen. In: A. Maczak and H.J. Teuteberg (eds.). Reiseberichte als Quellen europäischer Kulturgeschichte (= Wolfenbütteler Forschungen Bd. 21), pp. 1-32.

Harbsmeier, M. (1982b). Rejsebeskrivelser og mentalitetshistorie. Humaniora 5: 60-64.

Hassø, A.G. and E. Kroman. (eds.). (1973). Danish Department of Foreign Affairs until 1770. Vejledende arkivregistraturer XVI. Transl. M. Møller. Copenhagen: Rigsarkivet. https://www. sa.dk/wp-content/uploads/2016/12/VA-16-komp.pdf (accessed: 9.11.2021).

Helleberg, M. (1992). Fremmede naboer. En europæisk erfaring rigere. Polens historie. København: Gyldendal. 
Hirschberg, A. (1888). Z czasów niedoli i upadku. Ustęp z dziejów miasta Lwowa. Lwów: Zakład Narodowy im. Ossolińskich.

Jasnowski, J. (1960). Eastern Europe And Western Travellers During The Period Of The Grand Tour. The Polish Review 5(3): 31-36. http://www.jstor.org/stable/25776318 (accessed: 31.12.2020).

Jasnowski, J. (2008). Poland in the Eyes of the Western Travellers During the Period of Grand Tour (1550-1850). København: Polsk-Skandinavisk Forskningsinstitut.

Juel, J. and G. Grove. (1893). En Rejse til Rusland under Tsar Peter: Dagbogsoptegnelser af Viceadmiral Just Juel, dansk Gesandt i Rusland 1709-1711. København: Gyldendal.

Kamiński, A. (1966). Przeciwko Szwedom i Leszczyńskiemu. Działania wojsk rosyjskich na terenie Polski w 1705-1706 roku. Studia i Materiały do Historii Wojskowości 12(2): 234-235, 258.

Koczy, L. (1931). Akta polskie w Archiwum Państwowym w Kopenhadze. Archeion (9): 36-69.

Konopczyński, W. (1924). Polska a Szwecja: od pokoju oliwskiego do upadku Rzeczypospoplitej 1660-1795. Warszawa: Wydawnictwo Instytutu Popierania Polskiej Twórczości Naukowej p.n. Kasa Mianowskiego.

Koroluk, W. (1954). Polska i Rosja a Wojna Pótnocna. Warszawa: Książka i Wiedza.

Krokosz, P. (2010). Rosyjskie siły zbrojne za Piotra I. Kraków: Wydawnictwo Arcana.

Lanckorońska, C. (ed.). (1964-1974). Res Polonicae ex Archivo Regni Daniae. Romae: Institutum Historicum Polonicum Romae.

Liisberg, B. (ed.). (1919). Danmarks søfart og søhandel fra de aeldste tider til vore dage. Vol. 2. Copenhagen.

Lind, G. (1986). Den dansk-norske hær i det 18. århundrede. Optimering, modernisering og professionalisering. Historisk Tidsskrift 86(1): 26-72.

Lubas-Bartoszyńska, R. (2012). O Polsce i o Polakach w pozaantologijnych pismach osobistych cudzoziemców w XVIII i XIX wieku. Przestrzenie Teorii 17.

Maczak, A. (1995). Travel in Early Modern Europe. Cambridge: Polity Press.

Majewska, G. (2011). Szwedzkie elity w XVII i XVIII wieku o Polsce i jej mieszkańcach. In: B. Törnquist-Plewa (ed.). Polsk-skandinaviska möten. Lund: Centre for Language and Literature, Lund University, pp. 39-60.

Majewska, G. (2018). The Polish-Lithuanian commonwealth and its inhabitants during the Great Northern War in general Magnus Stenbock's opinion. Studia Maritima 31: 135-154. http:// doi.org/10.18276/sm.2018.31-07 (accessed: 9.11.2021).

Mączak, A. (1982). Dania i Rzeczpospolita w dobie nowożytnej. Problemy i perspektywy badań porównawczych. Zapiski Historyczne: poświęcone historii Pomorza i krajów bałtyckich 47(4): $167-180$.

Mączak, A. (1998). Odkrywanie Europy: podróże w czasach renesansu i baroku. Gdańsk: Novus Orbis.

Mishkova, D. and B. Trencsényi. (2017). European regions and boundaries: A conceptual history. London: SAGE Publications.

Morfill, W. (1895). Review of En Rejse til Rusland under Tsar Pete, by J. Juel \& G.L. Grove. The English Historical Review 10(40): 800-805. http://www.jstor.org/stable/548207 (accessed: 31.12.2020).

Møller, P.U. (1994). Reciprocal images: Russian culture in the mirror of travellers' accounts (based on the Kollekolle Conference, Copenhagen, 2-5 December 1994). Oslo: Scandinavian University Press.

Møller, P.U. (1997). The Russians as seen by three Danish travellers in the first half of the eighteenth century: Juel, Æreboe, von Haven. Culture \& History 14: 48-66.

Neumann, I. (1999). Uses of the Other. The 'East' in European Identity Formation. Minneapolis, MN: University of Minnesota Press. 
Niewiara, A. (2006). Procesy kategoryzacyjne a kulturowe konstruowanie obrazu 'innego' (Moskwicin - Moskal - Rosjanin). In: A. de Lazari (ed.). Katalog wzajemnych uprzedzeń Polaków i Rosjan. Warszawa: Polski Instytut Spraw Międzynarodowych.

Otwinowski, E. (1849). Dzieje Polski pod panowaniem Augusta II, 1696-1728. Kraków: nakładem i drukiem Józefa Czecha.

Papée, F. (1894, 1924). Historya miasta Lwowa w zarysie. Lwów: nakładem Gminy Król. Stoł. Miasta Lwowa, Gubrynowicz i Schmidt.

Paulli, R. (2011). Rasmus Æreboe i Dansk Biografisk Leksikon. https://biografiskleksikon.lex.dk/ Rasmus_\%C3\%86reboe (accessed: 10.11.2021).

Pepłowski, S. (1902). Cudzoziemcy w Galicji (1787-1841). Kraków: Spółka Wydawnicza Polska.

Poe, M. (1995). Foreign descriptions of Muscovy, an analytic bibliography of primary and secondary sources. Columbus, $\mathrm{OH}$ : Slavica.

Popiołek, B. (2002). Lwów w czasach Augusta II. In: K. Karolczak (ed.). Lwów: miasto, społeczeństwo, kultura: studia z dziejów Lwowa. Vol. 4. Kraków: Wydawnictwo Naukowe Akademii Pedagogicznej.

Popiołek, B. (2011). Swoi i obcy w mentalności szlachcianek polskich przełomu XVII i XVIII. In: "Своё" и "Чужое” в культуре. Сборник статей и материалов всероссийской научной конферениии с международным участием „Человек и мир человека” 20 мая 2010 года. Барнаул-Рубцовск: Издательство Алтайского университета, pp. 93-108.

Rabot, C. (1895). Pierre le Grand, d’après la correspondence de l’amiral danois Just Juel. Le Temps 2. http://catalogue.bnf.fr/ark:/12148/cb34431794k (accessed: 31.12.2020).

Radziwonka, R. (2019). Warszawa i jej mieszkańcy w czasach wielkiej wojny pótnocnej (17001721). Warszawa: Neriton.

Rambaud, A. (1894). Hors de France. Journal des Débats Politiques et Littéraires 1-2. http:// catalogue.bnf.fr/ark:/12148/cb39294634r (accessed: 31.12.2020).

Rolle, M. (1895a). Z dziennika podróży duńskiego posła Justa von Juel (w roku 1711). Świat 8(4): $177-178$.

Rolle, M. (1895b). Z dziennika podróży duńskiego posła Justa von Juel (w roku 1711). Świat 8(5): 203-204.

Rolle, M. (1895c). Z dziennika podróży duńskiego posła Justa von Juel (w roku 1711). Świat 8(6): 258-260, 278-282.

Rolle, M. (1908). Z minionych stuleci. Szkice historyczne i literackie. Lwów: Księgarnia Gubrynowicza i Schmidta.

Rolnik, D. (2002). Obraz Rosji i Rosjan w opiniach polskiej szlachty koronnej wschodnich Kresów Rzeczypospolitej w latach 1788-1793. Z dziejów stereotypu Rosji i Rosjan w Polsce doby nowożytnej. In: W. Bonusiak (ed.). Stereotypy narodowościowe na pograniczu. Rzeszów: Wydawnictwo Uniwersytetu Rzeszowskiego.

Schab, S. (2008). "Øjnene der ser..." Om berøringsflader mellem kulturer og om det eksotiske i en "nær" udgave. Dansk (rejse)litteratur om Polen. In: C. Zilliacus (ed.). Gränser i nordisk litteratur (= IASS XXVI 2006). Åbo: Åbo Akademis förlag, pp. 652-660.

Schab, S. (2018). Palimpsest polski. Reprezentacje Polski i Polaków w duńskich relacjach podróżniczych. Poznań: Wydawnictwo Naukowe UAM.

Schenk, F.B. (2002). Mental maps - The construction of geographic spaces in Europe since the Enlightenment. Geschichte Und Gesellschaft: Zeitschrift Für Historische Sozialwissenschaft 28(3): 493-514. https://doi.org/info:doi/ (accessed: 9.11.2021).

Slaski, K. (1974). Polsk-Danske Kulturelle Forbindelser I 16. Til 18. århundrede. Historie/ Jyske Samlinger 10 (januar). https://tidsskrift.dk/historiejyskesamling/article/view/39029 (accessed: 9.11.2021). 
Struck, B. (2005). Terra Incognita, European Civilization, and Colonized Land. Poland in Mid-eighteenth Century to Mid-nineteenth Century German Travel Accounts. In: H. Schulz-Forberg (ed.). Unravelling Civilisation. European Travel and Travel Writing. Brussels: Peter Lang, pp. 154-179.

Ślaski, K. (1967). Polonica w zbiorach szwedzkich, norweskich i duńskich. Kwartalnik Historyczny 74(1): 111-116.

Ślaski, K. (1977). Tysiąclecie polsko-skandynawskich stosunków kulturalnych. Wrocław: Ossolineum.

Topsøe-Jensen, T.A. and E. Marquard. (1935). Officerer i den Dansk-Norske Søetat 1660-1814 og den Danske Søetat 1814-1932. Kobenhavn: H. Hagerup.

VA XI, Tyske Kancelli II, p. 280 TKUA, Speciel del, Rusland.

Vuillaume, M. (1895). Pour les ivrognes. Le Radical 1. http://catalogue.bnf.fr/ark:/12148/ cb32847124t (accessed: 31.12.2020).

Weilbach, F. (1933). Frederik IV.s Italiensrejser. København: Levin \& Munksgaard.

Wilder, J. (1959). Okiem cudzoziemca. Ze wspomnień cudzoziemców o dawnej Polsce. Warszawa: Arkady.

Wimmer, J. (1956). Wojsko Rzeczypospolitej w dobie wojny pótnocnej (1700-1717). Warszawa: Wydawnictwo Ministerstwa Obrony Narodowej.

With, C. (1894). Entry: Just Juel. Dansk Biografisk Leksikon. Vol. 8. Kjobenhavn: Gyldendalske oghandels Forlag (F. Hegel \& Son).

Wolff, L. (1996). Inventing Eastern Europe, the map of civilization on the mind of the Enlightenment. London: Stanford University Press.

Zubrzycki, D. (1844). Kronika miasta Lwowa. Lwów: nakładem autora.

Агеева, О. (2003). Петровский Петербург глазами иностранцев. Отечественная история 3: $3-13$.

Возгрин, В. (1973). Документы Датского Государственного архива по истории России. Советские архивы 5: 102-105.

Возгрин, В. (1975). Заключение русско-датского наступательного союзного договора 1709 года. Исторические записки 93: 309-327.

Возгрин, В. (1982). Сведения о России XVI-XVIII вв. в переписке датских послов. Археографический ежегодник 148-151.

Возгрин, В. (1986). Россия и европейские страны в годы Северной войны (история дипломатических отношений в 1697-1710 г2.). Ленинград: Наука.

Крикун, М. (1993). Адміністративно-територіальний устрій Правобережної України в XV-VIII cm. Кордони воєводств у світлі джерел. Київ: Інститут української археографії.

Крикун, М. (2012). Воєводства Правобережної України у XVI-XVIII століттях. Львів: УКУ.

Мацевко, І., М. Мудрий (упоряд). (2016). У ратуші міста Львова... Від бурмистрів до міських голів. Львів: Галицька видавнича спілка.

Наливайко, Д. (2008). Україна очима Заходу. Київ: Основи.

Січинський, В. (1936). Данський посол про Козацьку Україну і Московщину. Літопис Червоної Калини. Львів: Червона Калина.

Шелухин, С. (1936-1937). Украӥна - назва нашої землі з найдавніших часів. Прага: Нова Україна.

Щербачев, Ю. (1900). Записки Юста Юля датскаго посланника при Петре Великом (1709-1711). Москва: Университетская типография. 